\title{
Danmark i krig? Besættelsens eftermæle
}

af professor, dr.phil. Henning Poulsen, Århus Universitet

Da "Survey of International Affairs" i 1954 præsenterede den første samlede fremstilling af det tyskbesatte Europa, i bogen Hitler's Europe, var der et udtryk, som stadig gik igen. Det var "except Denmark" - undtagen Danmark. Et besat land, ganske vist, men alligevel et, hvor de generelle karakteristikker ikke gjaldt.

Internationalt var man altså tidligt opmærksom på, at Danmark var et særtilfælde, og det var samtidens danske offentlighed sådan set også. Men da krigen sluttede, var det ikke noget, man var stolt af, og de forløbne 50 års debat har i høj grad været centreret om angreb, forsvar eller undskyldning for alt det, der skilte Danmark ud fra de allierede magter. Eller man ville sige de øvrige allierede magter, for da krigen sluttede i 1945 blev Danmark optaget i sejrherrernes klub, som stiftende medlem af De forenede Nationer i modsætning til f.eks. det neutrale Sverige.

Den opfattelse, at Danmark under 2. verdenskrig var at regne til de allierede, fordi det gennem sabotage og anden militær modstand ydede sit bidrag til HitlerTysklands nederlag, slog umiddelbart rod og har siden på alle mindedage - ikke mindst det 50-år, vi nylig oplevede - udgjort kernen i besættelsens eftermæle. Som udslag af national forfængeligehed er den let forklarlig, og i 1945 blev den ikke blot bestyrket af allieret anerkendelse, men også af, at der blev dannet en befrielsesregering, hvor modstandsbevægelsen gik sammen med de ledende parlamentarikere, der i de første år havde båret samarbejdet med besættelsesmagten, et samarbejde, som de nu var tilbøjelige til at fortolke som en forberedelse til den senere væbnede modstand.

Problemet var og er imidlertid, at en sådan strømliniet opfattelse støder på hårde 
forhindringer i de historiske data og slet ikke er egnet til at forklare Danmarks udvikling i disse år. Måske rummer den en vis psykologisk sandhed, da næsten alle kredse fra den første dag opfattede besættelsesmagten som fjendtlig. Men de faktiske forhold blev dikteret af andrte præmisser.

Ved besættelsen 9. april 1940 bøjede den danske regering sig i modsætning til den norske for Hitlers ultimatum, nedlagde våbnene og blev til gengæld fortsat anerkendt som leder af en suveræn stat, som Tyskland ikke var i krig med. Det fik til konsekvens, at Danmark frem til august 1943 styredes af en regering med støtte fra alle demokratiske partier, til efteråret 1942 endog med en socialdemokrat som regeringschef. På tysk hold varetoges forbindelsen til denne regering af udenrigs-tjenesten, Auswärtiges Amt i Berlin og det tyske gesandtskab i København. Der gjaldt ingen tysk forordningsret, og der blev ikke opbygget nogen tysk administration.

Forholdet til besættelsesmagten kom som i alle andre lande til at rumme både samarbejde og modstand. Men i Danmark fik samarbejdet en særlig form. Det lå ikke kun på det økonomiske, administrative og politimæssige plan. Det var et politisk samarbejde, et politisk spil og fulgte trods iøjnefaldende undtagelser i vidt omfang politikkens spilleregler. At dette også fik konsekvenser for modstandens form og vilkår, skal jeg vende tilbage til.

Naturligvis var det danske arrangement en vanskelig balancegang. I Hitlers øjne var Danmark "germansk" land, og danskernes skulle som nordmændene nazificeres og indlemmes i herrefolket i hans kommende storgermanske rige. Der var da også $\mathrm{i}$ efteråret 1940 tale om at følge eksemplet fra Norge og udskifte den parlamentariske med en nazistisk regering, og frem til vinteren 1942-43 fik de danske nazister økonomisk støtte og blev holdt i reserve som et muligt alternativ. Sluttede krigen med tysk sejr, var Hitler ikke sindet at bevare en demokratisk enklave i sit nye Europa.

De danske forhold var midlertidige. Men de holdt længe, og da den danske regering og rigsdag omsider 29. august 1943 efter strejker og uro i en række byer afviste klart uacceptable krav om indførelse af dødsstraf og gidseltagning og i konsekvens heraf nedlagde værktøjet, fandt Hitler ikke tiden passende til radikale forandringer. Efter 6 ugers militær undtagelsestilstand, hvorunder de danske værn blev opløst og en deportation af de danske jøder blev forsøgt, kørte den gamle ordning videre, omend på lavere plan. Regeringens forretninger blev overtaget af departementscheferne, stadig med den tyske udenrigstjeneste som modpart. Og 
stadig anerkendte Tyskland i princippet, at Danmark var suverænt, og at der ikke herskede krigstilstand.

Jeg skal ikke gå i detaljer med den politiske udvikling, men dog drage nogle vigtige karakteristika frem.

Først og fremmest bevarede de dansk-tyske relationer i væsentligt omfang deres politiske form. De tyske myndigheder kunne ikke give ordrer til deres danske kolleger. De kunne fremsætte krav til regeringen, siden departementscheferne, og de måtte så forhandles. Men forhandling er en proces, hvorunder det er nødvendigt at argumentere. Enhver politik er derfor indrammet af, hvad parterne anerkender som gyldige argumenter.

Den danske side af forhandlingsbordet måtte anerkende tyske interesser som gyldigt argument. Men ikke nazistiske. Støtten til de danske nazister foregik i hovedsagen i smug, og antisemitismen var frem til jødeaktionen i oktober 1943 stort set usynlig. Danske interesser havde naturligvis mindre vægt. Men på tysk side var tendensen dog at gribe mindst muligt ind i danske forhold. Således bevaredes en noget mere udstrakt ytringsfrihed, der f.eks. tillod politisk agitation for de demokratiske idealer, blot man undgik direkte at angribe Hitler-Tyskland.

Det er meget muligt, at den forsigtige og argumenterende tyske holdning førte til en optimal varetagelse af aktuelle tyske, først og fremmest økonomiske interesser. I handelsforhandlingerne fik Danmark lov at beholde så stor en part af landbrugsproduktionen, at rationerne blev højere end de tyske, og mangel på levnedsmidler aldrig opstod. Men det skete i erkendelse af, at Tyskland uden egen administration i landet aldrig ville være i stand til at føre en effektiv kontrol med de 200.000 danske brug. Det er heller ikke sandsynligt, at indførelse af tvangsarbejde ville have givet mere end de frivillige ordninger, som bevirkede, at der i efteråret 1941 var mere end 60.000 danske arbejdere beskæftiget i Tyskland, hvortil kom titusinder ved værnemagtsarbejder i Danmark. At besættelsen kun kostede Danmark 15\% af nationalproduktet mod 50\% i Norge og Belgien, er snarere udtryk for, at Danmarks ressourcer var vanskeligere at tage i anvendelse, end at de ikke blev udnyttet optimalt.

Den danske regerings politik havde ikke til formål at skade den tyske krigsførelse. Ja blot en neutralitetslinie, der kan sammenlignes med den svenske, søger vi forgæves efter. Den danske politik var begrænset til at bevare mest muligt af Danmarks selvstændighed, at holde Danmark ude af krigen og "at skåne landet og folket for en 


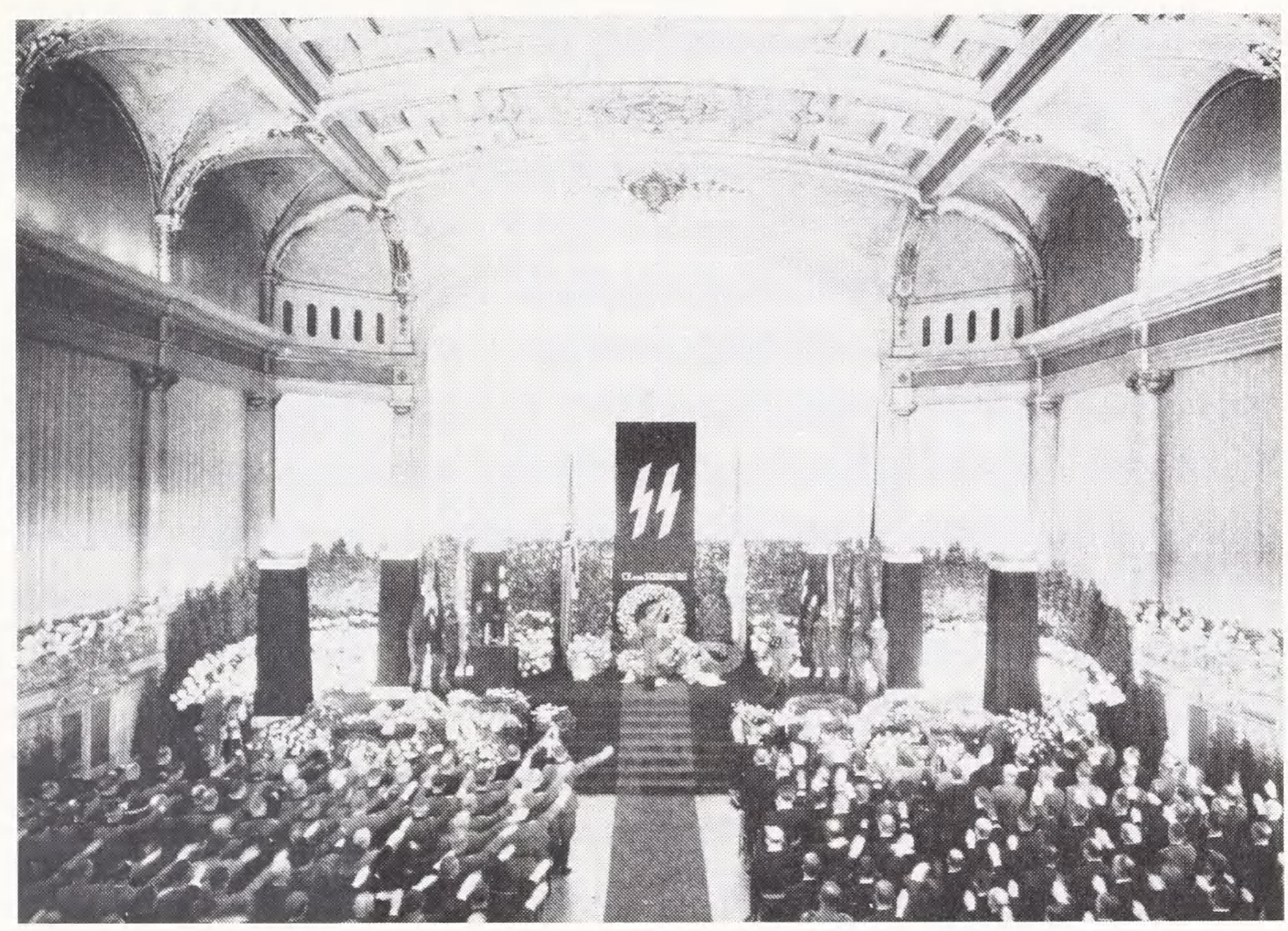

Lederen af Frikorps Danmark, Obersturmbannführer C.F. von Schalburg, faldt i kamp på Østfronten ved Ilmen-søen 2. juni 1942. Det benyttede DNSAP til at afholde en stort iscenesat "Mindeappel" i Odd Fellow Palæet 23. juni, hvor bl.a. den danske regering med statsminister Vilh. Buhl i spidsen, nogle generaler og det tyske gesandtskab var til stede. Altsammen i samarbejdspolitikkens ånd.

krigstilstands følger", som statsminister Stauning udtrykte det 9. april 1940. For at opnå dette var man villig til at gå ind i et samarbejde med besættelsesmagten, som også i regeringens egen kreds føltes ydmygende.

Her skiltes vandene mellem den danske stat og de modstandsgrupper, der opstod i 1942-43 og efterhånden samledes i, hvad vi kan betegne som en modstandsbevægelse. Den danske modstandsbevægelse var i modsætning til de fleste andre landes af offensiv, næsten rent militært karakter. Den var ikke et forsvar mod nazificering, tvangsarbejde eller andre tyske forsøg på at forandre samfundet. Det blev der under de givne forhold intet behov for. Den havde helt enkelt til formål at yde et dansk bidrag til den allierede sag, til Hitler-Tysklands nederlag.

Det bragte den og måtte nødvendigvis bringe den på kollisionskurs med regeringen og de demokratiske partier, hvis mål og politiske eksistensberettigelse var at holde befolkningen i ro. Modsætningen blev yderligere forstærket af, at den tidlige modstandsbevægelse i betydeligt omfang rekrutteredes fra de grupper på 
højre og venstre fløj, som blev skivet af, da man i 1940 dannede den nationale ssamlingsregering. Det vil især sige kommunisterne og højrenationale kredse. Til modsætning i aktuel strategi føjedes således en gennem år indarbejdet partipolitisk modsætning.

Der er ikke tvivl om, at den tidlige modstandsbevægelse så det som sit første mål at bringe det politiske samarbejde til ophør, og det lykkedes som nævnt i august 1943 gennem en serie af strejker og gadeuro i en række provinsbyer. Men netop disse strejker er et eksempel på, at også modstandsbevægelsen nød godt af de særlige danske forhold. Havde værnemagten reageret, som den gjorde i Norge og Holland, med hurtige dødsdomme, kunne strejkerne have været kvalt i fødslen. Men det gjorde den ikke, og det kunne den vanskeligt gøre. For skønt det var klart, at strejkerne var vendt mod besættelsesmagten, var de i sig selv kun en overtrædelse af overenskomsterne på det danske arbejdsmarked. Så man valgte også her fra tysk side at forhandle sig frem.

Det samme gentog sig under den store københavnske folkestrejke i sommeren 1944, der takket være en effektiv illegal dansk pressetjeneste skabte allieret opmærksomhed om dansk modstand. Heller ikke den var modstand ifølge de gængse definitioner, der lægger illegalitet til grund. Værnemagten skred nu hårdere ind og afbrød forsyningerne af vand, gas og el, men holdt sig stadig inden for rammerne af de forholdsregler ("Operation Monsun"), der var planlagt til imødegåelse af en opstand i en tysk by. Kun i de 6 uger efter bruddet 29. august 1943, da Danmark var erklæret i militær undtagelsestilstand, var strejker forbudt efter krigsretten. Og da var der ingen strejker i Danmark.

Noget lignende gælder den anden store bedrift, der gav genlyd i den allierede verden, nemlig den succesrige hjælp til de flygtende jøder i oktober 1943, da det lykkedes at bringe næsten alle til Sverige. Var den end et ægte udtryk for dansk afsky for antisemitismen, var hovedforklaringen dog igen tysk passivitet. Næsten intet blev gjort for at hindre flugten, og skønt de danske hjælpere sikkert havde ment at løbe en høj risiko, viste det sig, at de mange fiskere og andre, der blev taget af tysk politi ved hjemkomsten, kun blev stillet for dansk ret anklaget for hjælp til illegal udrejse, en forseelse, der højst var takseret til 3 måneders mildt fængsel. En hurtig tysk dødsdom havde også her givet et andet billede.

Et sidste eksempel på, at den danske modstandsbevægelse nød godt af den sam- 
arbejdspolitik, den bekæmpede, var Frøslevlejren, Europas mest ejendommelige koncentrationslejr placeret tæt nord for den dansk-tyske grænse. Af de 9.000 regulære danske modstandsfolk, der stod til deportation, nåede de 6.000 ikke længere end hertil, og det var en lejr, hvor det tyske vagtmandskab forlangte at få samme mad som fangerne. Den blev oprettet i 1944 på initiativ af de danske departementschefer og drevet af det danske fængselsvæsen. De tyske myndigheder var nok overrasket over forslaget, men havde svært ved at finde argumenter mod, at Danmark selv sørgede for forplejning af fanger, hvis arbejdskraft jo lige så godt kunne udnyttes nord som syd for grænsen. Det stred heller ikke mod nogen tysk interesse løbende at holde det danske socialministerium underrettet om, hvor danske KZ-lejrfanger i Tyskland befandt sig, så det kunne forsyne dem med Røde Kors-pakker, hvilket i kombination med Bernadotte-aktionen i foråret 1945 bevirkede, at $90 \%$ af fangerne overlevede.

Jeg skal på ingen måde hævde, at modstand i Danmark var risikofri. Ofrene løb op i mange hundrede menneskeliv, og tusinder, måske titusinder foretog handlinger, som de frygtede, kunne koste dem livet. Jeg skal heller ikke forsvare Gestapos fremfærd, der i krigens sidste år og måneder prægedes af stigende forråelse og ogsâ - på Hitlers udtrykkelige ordre - kom til at omfatte tilfældige drab på sagesløse. Men ser vi Danmarks besættelse i europæisk perspektiv, er det mest bemærkelsesværdige, at der her, midt i Hitlers imperium og midt i krigens ragnarok overlevede en ikke uvæsentlig rest af de former og regulerede handlemåder, vi betegner som civilisation.

For det, der gennem alle årene har gjort Hitler-Tyskland og især dets fremfærd under 2. verdenskrig til et skræmmende problem, er dets eklatante brud på den central- og vesteuropæiske civilisation, der var udviklet gennem århundreder. Der blev under hagekorsflaget begået forbrydelser, der ikke blot lader sig affeje som udslag af en gal mands luner, men demonstrerer civilisationens skrøbelighed. Forbrydelser, der på ingen måde var i almen tysk interesse, men dikteret af nazistiske paroler.

Sådan gik det i Berlin. Sådan gik det i Warszawa, i Oslo, i Paris og Amsterdam men sådan gik det ikke i København. Her overvintrede de gammeldags former. Den tyske øverstkommanderende søgte formelt audiens hos den danske konge, og gesandten gik selv vejen til det danske udenrigsministerium for at træffe den danske 
minister - ikke omvendt. Ligegyldigt måske - måske netop ikke.

Krigen kom ikke til København. Danmark, den danske stat, var ikke i krig. Og nazismen kom ikke til København. For hvem Tysklands repræsentanter end var, præsenterede de sig kun som tyskere, ikke som nazister. Werner Best, der i efteråret 1942 blev tysk rigsbefuldmægtiget, fik til Himmlers fortrydelse forbud mod at bruge sin titel som SS-Obergruppenführer. Rollerne var lagt til rette. Som embedsmænd og officerer og intet andet. Det er en urimelig tanke, at nazismen på kun 12 år skulle have gennemtrængt hele det tyske samfund. Elementer af civiliseret adfærd overlevede mange steder. I Danmark blev de dominerende.

I dansk overlevering er dette desværre et glemt aspekt. Sådan måtte det gå, da de fleste politikere i 1945 lod sig rive med af sejrsrusen og fornægtede eller undskyldte samarbejdspolitikken. Og sådan kunne det gå, fordi denne blev bragt til ophør næsten to år før krigens slutning, hvad der gav politikerne mulighed for at manøvrere sig ind $\mathrm{i}$ en ny position og sluttelig 5. maj 1945 træde frem i befrielsesregeringen skulder ved skulder med de gamle fjernder fra modstandsbevægelsen.

Udviklingen i de følgende år tjente også til at gøre de første besættelsesårs politiske samarbejde med Hitler-Tyskland uforståeligt. I historisk perspektiv knyttede det sig til den nationale selvforståelse, der i vekslende grad havde rådet siden krigsnederlaget i 1864, præget af frygt for Danmarks eksistens som stat og nation. Tysklands totale nederlag i 1945 fjernede denne frygt, og den storpolitiske udvikling førte til, at Danmark nu fik mulighed for at indtræde i en militær alliance, som medlem af NATO i 1949. Det var naturligt at se den nye oprustnings- og alliancepolitik i forlængelse af besættelsesårenes modstandsbevægelse, hvis efterkrigsmål netop havde været et opgør med den gamle neutralitet, der også i videre kredses vurdering havde lidt sit endegyldige nederlag den 9. april 1940.

Modstanden blev husket, tilpasningen glemt, undskyldt eller omfortolket. Men hvordan havde befolkningen under besættelsen taget parti for de to stridende danske holdninger?

Problemet er ikke så enkelt at løse. I de glade majdage i 1945 var der ikke ringeste tvivl om, at alle - bortset fra de få nazister - sluttede op om modstandsbevægelsen, og allerede den omfattende bølge af strjker og demonstrationer i august 1943 må opfattes som en folkelig manifestation af samme holdning. Herom ingen tvivl. Uden bred folkelig opbakning havde modstandsbevægelsen ikke været i stand til at operere, 
som den gjorde. Men betød det, at befolkningen tog afstand fra den politiske ledelse og dens bestræbelser for at opnå en modus vivendi med besættelsesmagten?

Logisk skulle det være sådan. De to linier var politisk uforenelige. Men det er ikke givet, at man i bredere kredse af befolkningen har opfattet modstand og samarbejde som et valg. Den tidlige modstandsbevægelse var helt på det rene med, at de samarbejdende partier havde bred støtte i befolkningen, og det tog den illegale presse hensyn til. Den angreb nok enkeltpersoner i regeringen, navnlig de upolitiske ministre, og også bestemte handlinger, så som den forfatningsstridige internering af ledende kommunister i juni 1941, tilslutningen til antikominternpagten i november samme år og meget andet. Men angreb på det politiske samarbejde som sådant var få og spredte. Også i de mange protestresclutioner, der blev vedtaget under Augustoprøret i 1943, leder vi forgæves efter krav om regeringens afgang og indførelse af "norske tilstande", som det hed.

Det har vakt undren, at urolighederne i august 1943 fulgte så kort efter rigsdagsvalget i marts, der blev en overvældende sejr for de samarbejdende, demokratiske partier, og det er dels forklaret ved, at dette valg kun opfattedes som en antinazistisk manifestation, dels ved et stemningsskifte i sommerens løb. Men det er tankevækkende, at det første efterkrigsvalg i oktober 1945 heller ikke kan betragtes som nogen fordømmelse af forhandlingspolitikken. Det borgerlige modstandsparti Dansk Samling fik et mådeligt valg, og skønt kommunisterne gjorde et betydeligt indhug i den socialdemokratiske vælgerskare, var det ikke større end det tilsvarende i det neutrale Sverige. Og de mest eksponerede samarbejdspolitikere, dem der havde været ministre under krigen, blev alle genvalgt med pæne personlige stemmetal.

Måske var de første år glemt. Måske Danmark blev ramt af den træthed ved helte, der altid lurer bag tribunen. Men nok så enkelt er det at antage, at modsætningen mellem tilpasning og modstand ikke lå og aldrig havde ligget højt i den brede befolknings bevidsthed. Konflikten overskyggedes af, at der på ét væsentligt punkt havde været koncensus, også på topplan, blandt de stridende eliter. Krigens gang var og blev det tema, der optog sindene mest. Og her var alle tilhængere af det samme hold. Sympatien lå udelt på allieret side. Alle havde krigen igennem set frem til det udfald, den fik, og alle kunne derfor med ærligt sind tage del i glædesfesten i maj 1945 og oprigtigt føle sig som sejrherrer.

Således var vejen også banet for retsopgøret, den gengældelse, som ramte dem, 


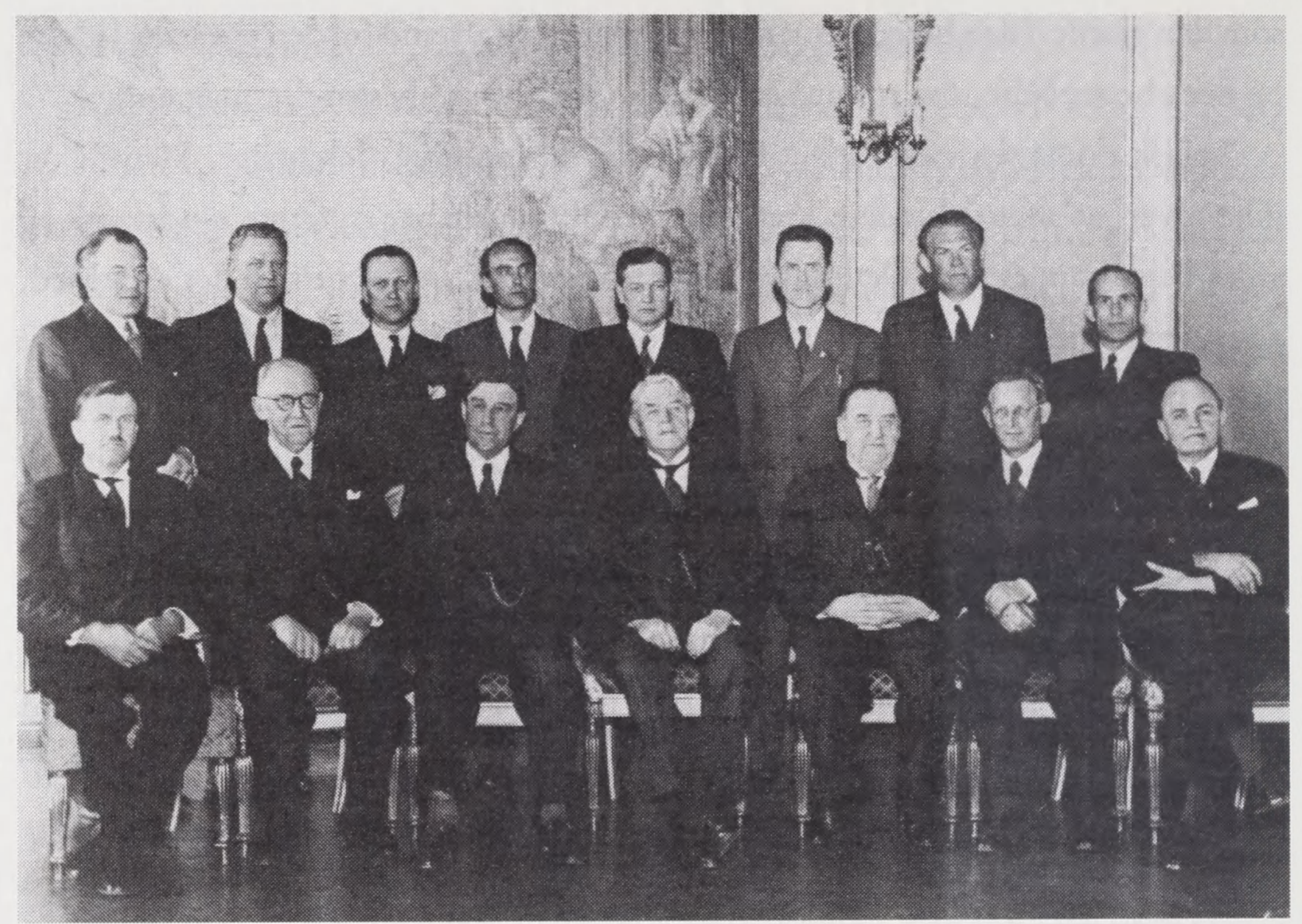

Befrielsesregeringen maj 1945 med lige dele repræsentanter for de politiske partier og modstandsbevægelsen. Enkelte ministre, bl.a. John Christmas Møller, er ikke kommet med på billedet.

der havde holdt på den forkerte hest. Dette skal jeg ikke gå nærmere ind på, men blot fremhæve, at det centrale begreb var landsforræderi. Processerne kunnne derfor ikke begrundes juridisk eller blot pseudojuridisk, medmindre man forudsatte, at Danmark havde taget del i krigen. På allieret side, naturligvis.

Enkelte jurister ytrede tvivl om denne forudsætnings holdbarhed. I hvert fald for perioden frem til 29. august 1943. Tiden derefter lod sig måske redde. For ganske vist havde den danske regering ikke ved sin afgang erklæret landet i krigstilstand. Men i sin proklamation af undtagelsestilstanden havde den øverstkommanderende for de tyske tropper i Danmark henvist til Haager-landkrigskonventionen, der jo forudsatte krig. Dog, desværre. Det var kun i den danske oversættelse, undtagelsestilstanden var erklæret "i Henhold til” denne konvention. I den tyske original stod der "Im Sinne", altså "analogt med", "på samme måde” - . Eller sagt på anden måde: selvom der ikke var krig og konventionen derfor egentlig ikke gjaldt.

I Danmark står vi altså i den paradoksale situation, at vi har vundet en krig, vi ikke har deltaget i - med mindre man da vil sige, at vi 5. maj 1945 indtrådte i 2. verdenskrig med tilbagevirkende kraft. Modstandsbevægelsen var en hær af frivillige 
i allieret tjeneste. $\mathrm{Al}$ respekt for det. Men den inddrog ikke den danske stat, og som tidligere nævnt bestemte Danmarks status som ikke-krigsførende også på væsentlige punkter modstandens art og vilkår.

Man få have os undskyldt, at vi som historikere har svært ved at forklare offentligheden dette. Vi kom godt igennem krigen og blev anerkendt som allieret uden at have taget del i den. Vi fik groft sagt smør på begge sider af brødet. Og man kan ikke engang sige, at det var en smart manøvre. For ingen havde villet det sådan. De populære intentionalistiske forklaringsmønstre kan ikke bruges.

Regeringens mål var at skåne befolkningen, og man må sige, det lykkedes. Men det var ikke dens hensigt at skabe vækstbetingelser for en militant modstandsbevægelse, hvis aktioner kostede den magten. Det var blot heldigt for den, at det gik sådan.

Modstandsbevægelsen havde på sin side som mål at få Danmark anerkendt som allieret. Og det lykkedes jo også. Men at den agerede og opnåede sine største resultater under betingelser, som var en konsekvens af den forhadte samarbejdspolitik, var en tanke, den ville have vist fra sig med afsky. Men det var heldigt for den, at det var sådan.

Danmarks historie under 2. verdenskrig er et fletværk af uforenelige politiske holdninger, der utilsigtet endte med at gå op i en højere enhed. Klarere kan det vel desværre ikke udtrykkes.

Foredrag holdt på den internationale historikerkonference Andre världkriget som myt och historia, Stockholm 21. august 1995 